\title{
Analisis Keputusan Konsumen dalam Melakukan Pembelian Beras Di Kabupaten Luwu
}

\author{
Andi Rizkiyah Hasbi ${ }^{1}$, Astrini Padapi ${ }^{2}$, Sari Ratna Dewi ${ }^{3}$ \\ 1, 3 Program Studi Manajemen Universitas Muhammadiyah Palopo \\ ${ }^{2}$ Program Studi Agribisnis Universitas Muhammadiyah Sidenreng Rappang \\ *Email: andirizkiyahhasbi@gmail.com
}

\begin{abstract}
Abstrak
Sebagai bahan makanan pokok bagi mayoritas penduduk Indonesia, kebutuhan beras terus mengalami peningkatan setiap tahunnya. Pada dasarnya, konsumen membeli produk yang dapat memuaskan keinginan tidak hanya dalam bentuk fisik tetapi juga manfaat kualitas dari produk tersebut. Kualitas produk dan harga merupakan faktor penentu kepuasan konsumen setelah melakukan pembelian dan pemakaian terhadap suatu produk. Tujuan penelitian ini adalah untuk menganalisis apakah harga dan Kualitas berpengaruh positif dan signifikan terhadap keputusan pembelian Beras di Kabupaten Luwu . Penelitian ini menggunakan pendekatan kuantitatif. Metode yang digunakan untuk penelitian ini adalah dengan menyebarkan lembar kuesioner, yang diukur menggunakan metode skala likert dengan subyek penelitian adalah konsumen beras di Kabupaten Luwu. Berdasarkan data yang diperoleh dari hasil penelitian dapat disimpulkan bahwa secara simultan atau bersama-sama harga dan kualitas produk berpengaruh signifikan terhadap Keputusan pembelian beras di Kabupaten Luwu, Harga secara parsial berpengaruh signifikan terhadap Keputusan pembelian beras di Kabupaten Luwu dan Kualitas Produk secara parsial berpengaruh signifikan terhadap Keputusan pembelian beras di Kabupaten Luwu.
\end{abstract}

Keywords: Beras, Harga, Kualitas, Keputusan Konsumen

\section{Pendahuluan}

Indonesia dikenal sebagai negara agraris yang masyarakatnya sebagian besar berprofesi sebagai petani dan terbukti menghasilkan bahan pangan contohnya seperti beras. Pelaku-pelaku bisnis selalu memiliki berbagai cara agar produknya dapat mengungguli produk lain. Agar produknya dapat bersaing, maka kualitas produk harus ditingkatkan sehingga volume penjualan juga dapat meningkat. Setiap produsen harus bisa menjaga kualitas produk dan menentukan harga yang tepat agar mendapat kepercayaan dan loyalitas dari konsumen. Jika produk yang dijual memiliki kualitas yang bagus dengan harga yang sesuai maka diharapkan mampu bersaing dengan pesaingpesaingnya. Kualitas produk dan harga dapat mempengaruhi volume penjualan.

Peningkatan jumlah penduduk yang menyebabkan permintaan tanaman pangan khususnya beras juga meningkat, haruslah sebanding dengan peningkatan produktivitas padi. Salah satu upaya dalam meningkatkan produktivitas hasil tanaman padi dengan penambahan luas lahan sehingga dapat memenuhi kebutuhan masyarakat.

Kabupaten Luwu merupakan daerah penghasil beras berkualitas dengan harga di atas rata-rata tentunya disayangkan apabila tidak memberikan kepuasan bagi pelanggan yang mengkonsumsinya. Hal itu tentu dapat menimbulkan masalah dalam pemasaran mengingat banyaknya produk beras sejenis yang memiliki kualitas mutu yang baik dan pada akhirnya berdampak pada penjualan. Untuk menuju cara ini, maka perlu memfokuskan cara pemasaran yang paling tepat agar tercapaisasaransasarannya.

Harga merupakan salah satu faktor utama konsumen dalam mempertimbangkan keputusan belinya. Lupiyoadi (2004) menyatakan bahwa harga suatu produk sangat signifikan dalam pemberian value kepada konsumen untuk membeli suatu produk. Harga yang sesuai dengan kualitas produknya maka konsumen akan tertarik untuk membeli produk tersebut karena konsumen tidak selalu terpaku dengan harga yang rendah

Namun pada dasarnya, konsumen membeli produk yang dapat memuaskan keinginan tidak hanya dalam bentuk fisik tetapi juga manfaat kualitas dari produk tersebut. Kualitas produk merupakan faktor penentu kepuasan konsumen setelah melakukan pembelian dan pemakaian terhadap suatu produk. Konsep Produk menyatakan konsumen akan lebih menyukai produk-produk yang menawarkan paling bermutu, berprestasi atau inovatif. Competitor gula aren sawit di Desa Simpang Empat berusaha melayani kebutuhan konsumen dengan produk yang ditawarkan sesuai dengan keiginan dan kebutuhan konsumen (Kotler dan Keller, 2007)

Harga dan kualitas beras merupakan hal penting yang diperhatikan dalam melakukan pembelian suatu barang. Produk-produk berkualitas yang dibuat melalui suatu proses akan memiliki sejumlah keistimewaan yang mampu meningkatkan kepuasan konsumen atas penggunaan produk itu. Karena setiap konsumen pada umumnya akan memaksimumkan utilitas dalam mengkonsumsi produk, jelas bahwa produk-produk berkualitas tinggi pada tingkat harga yang kompetitif akan dipilih oleh konsumen. Hal ini yang akan meningkatkan penjualan dari penjualan dari produk. Berdasarkan latar belakang yang telah diuraikan diatas, maka dalam penelitian ini penulis mengambil judul : "Analisis keputusan konsumen dalam melakukan pembelian Beras di Kabupaten Luwu”. 


\section{Kerangka Teori}

\subsection{Harga}

Harga adalah jumlah dari seluruh nilai-nilai yang ditukar konsumen atas manfaat-manfaaat memiliki atau mengggunakan produk atau jasa tersebut Harga juga merupakan faktor penentu yang mempengaruhi pilihan pembelian, hal ini masih menjadi kenyataan di negaranegara dunia, dikalangan kelompok-kelompok sosial yang miskin, serta pada bahan-bahan pokok sehari-hari. Namun dalam dasawarsa terakhir ini, faktor-faktor lain selain harga telah beralih menjadi relatif lebih penting dalam proses pembelian. Harga dapat menunjukkan kualitas dari suatu produk, dimana konsumen mempunyai anggapan bahwa harga yang mahal biasanya mempunyai kualitas yang baik. Pada umumnya harga mempunyai pengaruh yang positif dengan kualitas, semakin tinggi harga maka semakin tinggi kualitas.

Menurut Machfoedz (2010) harga adalah jumlah uang yang dikenakan pada produk atau jasa. Definisi harga secara luas ialah jumlah nilai yang ditukar oleh konsumen untuk memperoleh manfaat kepemilikan atau penggunaan suatu produk atau jasa. Harga merupakan satu-satunya elemen bauran pemasaran yang menghasilkan pendapatan, unsur lainnya mencerminkan biaya.

\subsection{Kualitas}

Menurut Kotler dan Amstrong (2006) kualitas produk merupakan salah satu sarana positioning utama pasar. Kualitas produk mempunyai dampak langsung pada kinerja produk atau jasa, oleh karena itu kualitas berhubungan erat dengan nilai pelanggan. Dalam artian sempit kualitas bisa didefinisikan sebagai bebas dari kerusakan. Menurut Tjiptono (2001) kualitas produk adalah suatu kondisi dinamis yang berhubungan dengan produk, jasa, manusia, proses, dan lingkungan yang memenuhi atau melebihi harapan

Sedangkan Menurut Kotler (2001) menyatakan bahwa kualitas produk adalah kemampuan produk untuk melaksanakan fungsinya, termasuk di dalam keawetan, keandalan, ketepatan, kemudahan pemakaian dan diperbaiki serta atribut bernilai lainnya. Konsumen akan merasa puas bila hasil evaluasi mereka menunjukkan bahwa produk yang mereka gunakan berkualitas. Melalui Pengertian dan teori ini dapat diketahui bahwa suatu barang atau jasa akan dinilai bermutu apabila dapat memenuhi ekspektasi konsumen akan nilai produk yang diberikan kepada konsumen tersebut. Artinya, mutu atau kualitas merupakan salah satu faktor yang menentukan penilaian kepuasan konsumen

\subsection{Keputusan Konsumen}

Konsumen membentuk preferensi atas merekmerek yang ada di dalam kumpulan pilihan (tahap evaluasi). Konsumen tersebut juga dapat membentuk niat untuk membeli merek yang paling disukai.

Indikator untuk mengukur keputusan pembelian menurut (Kotler, 2008) yaitu:

1) Kemantapan pada sebuah produk, merupakan keputusan yang dilakukan konsumen, setelah mempertimbangkan berbagai informasi yang mendukung pengambilan keputusan.
2) Kebiasaan dalam membeli produk, yaitu seseorang akan cenderung melakukan pembelian produk yang sama secara berulang-ulang.

3) Memberikan rekomendasi kepada orang lain, merupakan penyampaian informasi yang positif kepada orang lain, agar tertarik untuk melakukan pembelian dan mengenal produk tersebut.Melakukan pembelian ulang, merupakan kecenderungan konsumen untuk selalu membeli ulang produk yang telah dikonsumsinya.

Adapun faktor-faktor yang mempengaruhi konsumen dalam melakukan keputusan pembelian menurut (Suryani, 2008)adalah sebagai berikut :

1. Produk

Alat bauran pemasaran yang paling mendasar adalah produk. Produk merupakan segala sesuatu yang dapat ditawarkan produsen untuk diperhatikan, dicari, dibeli, digunakan, atau dikonsumsi pasar sebagai pemenuhan kebutuhan atau keinginan pasar yang bersangkutan. Produk yang dimaksudkan dalam hal ini dapat berupa barang secara fisik, jasa, jasa, kepribadian, tempat, organisasi, dan gagasan atau ide.

\section{Harga}

Sebelum memasarkan produknya di pasar, perusahaan perlu menetapkan harga produk tersebut. Harga adalah merupakan salah satu unsur perusahaan yang penting dalam dunia perdagangan dewasa ini khususnya dalam dunia persaingan bagi setiap perusahaan.

\section{Promosi}

Promosi merupakan salah satu aspek penting pemasaran, sebab promosi dapat mempengaruhi perilaku konsumen, terhadap produk perusahaan. Disamping itu promosi dapat digunakan sebagai komunikasi antara produsen kekonsumen. Promosi juga merupakan sarana dalam memperkenalkan jenis, harga, bentuk, warna dan kualitas dari produk yang dihasilkan.

\section{Place}

Pengusaha haruslah menyebarkan barang-barangnya ke tempat konsumen itu berbeda. Hal ini merupakan tugas untuk mendistribusikan barangnya kepada konsumen. Untuk keperluan tersebut pengusaha dapat menggunakan berbagai bentuk saluran distribusi yang mungkin dilakukannya.

\section{Metodologi}

Penelitian ini menggunakan metode kuantitatif. Metode penelitian kuantitatif dapat diartikan sebagai metode penelitian yang berlandaskan pada filsafat positivisme, digunakan untuk meneliti pada populasi atau sampel tertentu, teknik pengambilan sampel pada umumnya dilakukan secara random, pengumpulan data menggunakan instrument penelitian, analisis data bersifat kuantitatif/statistik dengan tujuan untuk menguji hipotesis yang telah ditetapkan (Sugiyono, 2014)

Pengumpulan data menggunakan metode observasi dan wawancara. Metode observasi merupakan suatu proses yang kompleks, suatu proses yang tersusun dari berbagai proses biologis dan psikologis. Metode wawancara digunakan sebagai teknik pengumpulan data apabila peneliti 
ingin melakukan studi pendahuluan untuk menemukan permasalahan yang harus diteliti, dan juga apabila peneliti ingin mengetahui hal-hal dari responden yang lebih mendalam dan jumlah respondennya sedikit atau kecil (Sugiyono, 2014).

\section{Hasil}

Analisis regresi linear berganda yaitu suatu metode yang digunakan untuk menentukan ketepatan prediksi dari pengaruh yang terjadi antara variabel in dependen atau Variabel Harga dan Kualitas Produk, terhadap dependen atau keputusan pembelian (Y). Perhitungan statistik dalam analisis regresi linear berganda yang digunakan dalam penelitian ini adalah dengan menggunakan bantuan program komputer SPSS Versi 23. Hasil pengolahan data dengan menggunakan program SPSS selengkapnya ada pada lampiran dan selanjutnya diringkas sebagi berikut :

\section{a. Uji Serempak $(U j i F)$}

Uji $\mathrm{F}$ digunakan untuk menguji pengaruh variabel independen yaitu Harga, Kualitas Produk, promosi dan brand image terhadap dependen yaitu keputusan pembelian hal ini dapat dilihat pada tabel berikut:

Tabel 1 Hasil Analisis Uji Serempak (Uji F)

$$
\text { ANOVA }{ }^{\mathrm{a}}
$$

\begin{tabular}{|l|r|r|r|r|r|}
\hline Model & \multicolumn{1}{|c|}{$\begin{array}{c}\text { Sum of } \\
\text { Squares }\end{array}$} & df & $\begin{array}{c}\text { Mean } \\
\text { Square }\end{array}$ & F & $\begin{array}{c}\text { Sig } \\
\text {. }\end{array}$ \\
\hline \multicolumn{1}{|c|}{ Regression } & 785.970 & 2 & 392.985 & 247.823 & $\begin{array}{r}.00 \\
0^{\mathrm{b}}\end{array}$ \\
Residual & 74.530 & 47 & 1.586 & & \\
\multicolumn{1}{|c|}{ Total } & 860.500 & 49 & & & \\
\hline
\end{tabular}

a. Dependent Variable: Keputusan Pembelian

b. Predictors: (Constant), Kualitas Produk, Harga

Nilai $F_{\text {hitung }}$ untuk variabel harga dan kualitas produk secara simultan sebesar 247,8> nilai $F_{\text {tabel }}$ yaitu 2,57 dan signifikansi sebesar $0,000<0,05$, maka dapat disimpulkan bahwa harga dan kualitas produk secara simultan berpengaruh siginifikan terhadap variabel Keputusan pembelian beras di Kabupaten Luwu.

b. Uji Parsial (Uji-t)

Uji parsial (uji-t) bertujuan untuk mengetahui besar pengaruh variabel independen terhadap variabel dependen secara parsial. Besarnya pengaruh tiap variabel independen terhadap variabel dependen dilihat dari nilai koefisien regresi. Hasil uji-t dapat dilihat pada tabel berikut.

Tabel 2. Hasil Analisis Uji T

\begin{tabular}{|c|c|c|c|c|c|}
\hline & & Coeff & ien & & \\
\hline \multirow[t]{2}{*}{ Model } & \multicolumn{2}{|c|}{$\begin{array}{l}\text { Unstandardize } \\
\text { d Coefficients }\end{array}$} & \multirow{2}{*}{$\begin{array}{l}\text { Standardized } \\
\text { Coefficients }\end{array}$} & \multirow[t]{2}{*}{$\mathrm{t}$} & \multirow[t]{2}{*}{ Sig. } \\
\hline & B & $\begin{array}{l}\text { Std. } \\
\text { Error }\end{array}$ & & & \\
\hline (Constant & 5.929 & 2.676 & & -2.216 & .032 \\
\hline 1 Harga & .285 & .074 & .276 & 3.845 & .000 \\
\hline $\begin{array}{l}\text { Kualitas } \\
\text { Produk }\end{array}$ & .674 & .067 & .720 & 10.032 & .000 \\
\hline
\end{tabular}

a. Dependent Variable: Keputusan Pembelian
Berdasarkan hasil analsis data dengan menggunakan program SPSS pada tabel 22 maka dapat disimpulkan bahwa:

1. Nilai $\mathrm{T}_{\text {hitung }}$ untuk variabel Harga (X1), sebesar $3.845>$ nilai $\mathrm{T}_{\text {tabel }}$ yaitu 2,014 dan signifikansi sebesar $0,000<$ 0,05, maka dapat disimpulkan bahwa Harga secara parsial berpengaruh signifikan terhadap Keputusan pembelian beras di Kabupaten Luwu.

2. Nilai $T_{\text {hitung }}$ untuk variabel Kualitas Produk (X2) sebesar $10.032>$ nilai $\mathrm{T}_{\text {tabel }}$ yaitu 2,014 dan signifikansi sebesar $0,000<0,05$, maka dapat disimpulkan bahwa Kualitas produk secara parsial berpengaruh signifikan terhadap Keputusan pembelian beras di Kabupaten Luwu .

\section{Pembahasan}

Pembahasan dalam penelitian ini mengenai pengaruh harga dan kualitas terhadap keputusan pembelian beras di Kabupaten Luwu. Hasil penelitian menunjukkan bahwa semua variabel kualitas produk dan harga merupakan variabel yang berpengaruh terhadap variabel terikat yaitu keputusan pembelian. Hal ini sesuai dengan penelitian yang dilakukan Faisal dan Lisarini (2004) bahwa faktor yang mempengaruhi kepuasan konsumen beras Pandanwangi secara bersamasama adalah kualitas produk dan harga produk.Pengaruh signifikan secara parsial variable bebas terhadap variable terikat adalah pengaruh dari butir beras tidak utuh, butir bers utuh, harga sesuai dengan harapan dan adanya potongan harga.

Frendy O. Mokalu dan Altje Tumbel (2015), melakukan penelitian dengan judul pengaruh kualitas produk, harga dan distribusi terhadap volume penjualan Roti Jordan CV. Minahasa Mantap Perkasa dengan menggunakan regresi linear berganda menemukan dari semua variabel independen secara bersama-sama berpengaruh terhadap volume penjualan.

Adapun hasil pengujian variabel harga menunjukkan bahwa memiliki pengaruh terhadap keputusan pembelian beras di Kabupaten Luwu. Menurut Chandra dalam Tjiptono (2012) harga merupakan pernyataan nilai dari suatu produk. Harga menentukan beli dan penentu bagi konsumen membelisuatu produk untuk memperoleh manfaat dari produk tersebut. Menurut kotler dan Amstrong (2009) yang menyatakan bahwa harga merupakan sejumlah uang yang ditagihkan atas suatu produk atau jumlah dari nilai yang ditukarkan para pelanggan untuk memperoleh manfaat dari memiliki atau menggunakan suatu produk atau jasa.

Hasil pengujian hipotesis menunjukkan bahwa variabel kualitas produk memiliki pengaruh yang besar terhadap keputusan pembelian beras di Kabupaten Luwu. Hal ini menunjukan bahwa kualitas produk memiliki nilai yang positif terhadap penjualan sehingga semakin berkualitasnya produk yang ada pada beras maka akan mendorong konsumen untuk melakukan pembelian. Apabila sebuah produk memiliki kualitas yang sudah terjamin maka konsumen tidak lagi melirik produk lain dan akan melakukan pembelian produk yang sudah jelas kualitasnya. Menurut Kotler \& Amastrong menyatakan 
bahwa kualitas produk merupakan senjata strategi potensial untuk mengalahkan pesaing. Wongpornchai et al. (2004) yang menyatakan bahwa banyaknya jenis beras yang beredar dipasaran menimbulkan tuntutan terhadap peningkatan mutu, baik penampilan, mutu masak, aupun aroma.

\section{Kesimpulan}

Berdasarkan data yang diperoleh dari hasil penelitian dapat disimpulkan bahwa secara simultan atau bersama-sama harga dan kualitas produk berpengaruh signifikan terhadap Keputusan pembelian beras di Kabupaten Luwu, Harga secara parsial berpengaruh signifikan terhadap Keputusan pembelian beras di Kabupaten Luwu dan Kualitas Produk secara parsial berpengaruh signifikan terhadap Keputusan pembelian beras di Kabupaten Luwu.

\section{Daftar Pustaka}

Faisal R., Lisarini e., 2015. Pengaruh Kualitas Dan Harga Beras Pandanwangi Terhadapkepuasan Konsumen Di Wilayah Pemasaran Cianjur. Jurnal agroscience 5 (2), 1-6.

Kotler, Philip dan Gary Amstrong, 2006, Prinsip-Prinsip Pemasaran, Jilid 1, Edisi 12, Terjemahan: Bob Sabran, M.M, Jakarta: Erlangga

Kotler dan Kevin Lane Keller, 2007. Manajemen Pemasaran. Jakarta: PT.Indeks

Kotler, Philip. 2008. Manajemen Pemasaran Edisi 12 Jilid 2. Jakarta: Indeks

Machfoedz, Mahmud. 2010. Komunikasi Pemasaran Modern. Yogyakarta : Cakra Ilmu.

Mokalu, F. O. dan Tumbel, A. 2015. Pengaruh Kualitas Produk, Harga dan Distribusi Terhadap Volume Penjualan Roti Jordan CV. Minahasa Mantap Perkasa. Jurnal EMBA. Vol. 3 No.1 Maret 2015, Hal. 254-265

Rambat, Lupiyoadi. 2004. Manajemen Pemasaran Jasa : Teori dan Praktek. Jakarta: PT Salemba Empat.

Sugiyono. (2014). Metode Penelitian Pendidikan Pendekatan Kuantitatif, Kualitatif, dan R\&D. Bandung: Alfabeta.

Tjiptono. 2001. Manajemen Pemasaran dan Analisa Perilaku Konsumen, Yogyakarta: BPFE.

Tatik Suryani, Perilaku Konsumen Implikasi Pada Strategi Pemasaran, (Yogyakarta: Graha Ilmu, 2008)

Wongpornchai, S., K. Dumri, S. Jongkaewwattana., and B. Siri. 2004. Effect of Drying Methode and Storage Time on the Aroma and Milling Quality of Rice (Oryza sativa L.) cv. Khao Dawk Mali 105. Journal Food Chemistry 87(3) : 407-414 